\title{
The Lubanga Judgment of the ICC: More than just the First Step?
}

Thomas R. Liefländer

\section{Keywords}

International criminal law, International Criminal Court, child soldiers, Thomas Lubanga

On 14 March 2012, Trial Chamber (TC) I of the International Criminal Court (ICC) issued its judgment in the case against Thomas Lubanga Dyilo, finding him guilty of co-perpetrating the crimes of enlisting and conscripting child soldiers and using them to participate actively in hostilities under Article 8(2)(e)(vii) of the Rome Statute. ${ }^{1}$ The Chamber found that Thomas Lubanga, leader of the Union des Patriotes Congolais (UPC) and its military arm, the Forces patriotiques pour la libération du Congo (FPLC), and others came together with the intent of "build[ing] an army for the purpose of establishing and maintaining political and military control over Ituri", which "resulted, in the ordinary course of events, in the conscription and enlistment of boys and girls under the age of 15 , and their use to participate actively in hostilities". ${ }^{2}$ Lubanga was further found to have made an essential contribution to implementing the common plan and to have done so with the requisite mens rea. ${ }^{3}$

The judgment is the first trial judgment issued by the ICC and marks a historical moment. Undoubtedly, this is a cause for celebration: more than 13 years after the adoption of the Rome Statute 4 and almost 10 years after the ICC came to life, the first trial has finally been concluded. In this brief case note, however, I do not intend to celebrate the historical importance of the Lubanga judgment. I will also not devote much attention to the process that led up to the judgment and the various procedural obstacles that had to be overcome along

\footnotetext{
BA (Dresden), LLM (Leiden), MSt candidate (St Hugh's College, Oxon).

1 Prosecutor $v$ Thomas Lubanga Dyilo, Judgment Pursuant to Article 74 of the Statute, Trial Chamber I, ICC-01/04-01/06, 2012 (hereinafter 'Judgment'), para. 1358.

2 Ibid., para. 1351.

3 Ibid., paras. 1356-7.

41998 Statute of the International Criminal Court, 2187 UNTS 90 (hereinafter 'Rome Statute').
} 
the way, having threatened to stall the entire trial twice. ${ }^{5}$ What I am more interested in doing is exploring the judgment's jurisprudential significance. Introducing a symposium on Pre-Trial Chamber (PTC) I's confirmation of charges decision, William Schabas and Carsten Stahn wrote that "in a few years, hardly anyone will recall the precise facts and counts brought forward against [Lubanga]", predicting that the case's jurisprudential impact would result more from the legal pronouncements. ${ }^{6}$

The Lubanga case has, unsurprisingly, been compared with the Tadic case before the International Criminal Tribunal for the former Yugoslavia (ICTY), which gave rise to some of the most widely-cited dicta in the field of international criminal law. Whether the Lubanga judgment will gain similar prominence remains to be seen. On the one hand, this will certainly depend on the legal findings made by the TC and how central these prove to be in future cases. As I will analyze below, the TC did make some important contributions to the clarification of many of the Rome Statute's provisions; however, overall these contributions appear rather modest. On the other hand, major contributions were perhaps never to be expected of this judgment.

This may be so for two reasons. First, while the Lubanga judgment is the first trial judgment of the ICC, it is certainly not the first judicial pronouncement on several of the legal issues arising in the case. The last years have shown that in issuing confirmation of charges decisions, the ICC PTCs have taken it upon themselves to elaborate on the relevant law in great depth. ${ }^{7}$ This certainly holds true for the Lubang a case itself, where PTC I covered the relevant legal questions in detail. ${ }^{8}$ In this light, the PTC had already stolen the TC's thunder, to some degree, before the latter even started hearing the case. ${ }^{9}$ The second reason for not expecting too much of this case is that the charges brought against Thomas Lubanga were so narrow that they simply did not give the judges much of a chance to pronounce themselves on the law more broadly.

${ }^{5}$ See Judgment, para. 10.

${ }^{6}$ W. Schabas \& C. Stahn, 'Introductory Note: Legal Aspects of the Lubanga Case', (2008) 19 Criminal Law Forum 431, at 431.

7 Cf. R. Cryer et al., An Introduction to International Criminal Law and Procedure (CUP, 2010), at 461.

8 See Prosecutor $v$ Thomas Lubanga Dyilo, Decision on the Confirmation of Charges, Pre-Trial Chamber I, ICC-01/04-01/06, 2007 (hereinafter 'Lubanga Confirmation Decision').

9 Thomas Weigend even speculated that Judge Jorda, who sat on the PTC and resigned shortly after issuing the confirmation of charges decision, wanted to use that decision to leave his mark on the ICC's case-law. T. Weigend, 'Intent, Mistake of Law and Co-perpetration in the Lubanga Decision on Confirmation of Charges', (2008) 6 Journal of International Criminal Justice 471, at 472. 
All this being said, the TC did express views on a number of important questions. I will comment on five particular subject areas: the classification of armed conflicts (1); the definition of the crime of enlisting, conscripting and using child soldiers (2); the mental element of criminal liability (3); the status of victim-witnesses that have been found to provide unreliable evidence (4); and the review of statements of law made by the PTC (5).

\section{The classification of armed conflicts}

The Rome Statute contains two almost identical provisions prohibiting "[c]onscripting or enlisting children under the age of fifteen years into the [national armed forces/armed forces or groups] or using them to participate actively in hostilities", ${ }^{10}$ one applicable to international armed conflicts and one applying in armed conflicts of a non-international character. The Prosecution had only charged Lubanga with the crime applicable to non-international armed conflicts. ${ }^{11}$ The PTC, however, assumed that it had the power under Article 61(7)(c)(ii) to single-handedly re-characterize the facts (rather than to ask the Prosecutor to do so), and decided that for the most part the armed conflict in question (between July 2002 and 2 June 2003) was one of an international character, due to the presence of the Ugandan army as an occupying power in parts of Ituri. ${ }^{12}$ The TC chose a different path. While the PTC had taken the view that the occupation by Uganda rendered the entire conflict in Ituri international, the TC relied on a relational concept of armed conflict by focusing on the status of the two parties to the conflict. In this connection, it accepted that "international and non-international conflicts may coexist". ${ }^{13}$ For the purpose of determining the law that should apply to any given act, the Chamber stated that "[in] situations where conflicts of a different nature take place on a single territory, it is necessary to consider whether criminal acts under consideration were commit-

\footnotetext{
${ }^{10}$ Art. 8(2)(b)(xxvi) and 8(2)(e)(vii), Rome Statute, supra, note 4.

${ }^{11}$ Prosecutor $v$ Thomas Lubanga Dyilo, Document Containing the Charges, Article 61(3)(a), Pre-Trial Chamber I, ICC-01/04-01/06, 2006, at 24.

${ }^{12}$ Lubanga Confirmation Decision, para. 220. According to Article 61(7)(c)(ii) of the Rome Statute, the PTC may "[adjourn] the hearing and request the Prosecutor to consider ... [amending] a charge because the evidence submitted appears to establish a different crime within the jurisdiction of the Court". For the PTC's reasoning with respect to its decision not to follow the procedure prescribed in this provision, see Lubanga Confirmation Decision, paras. 203-4.

${ }^{13}$ Judgment, para. 540.
} 
ted as part of an international or a non-international conflict". ${ }^{14}$ On this basis, the TC had to determine whether the particular armed conflict in which the UPC was engaged was of an international or of a non-international character.

In considering when an armed conflict involving non-governmental groups could be considered international in nature, the TC held that:

[i]t is widely accepted that when a State enters into conflict with a non-governmental armed group located in the territory of a neighboring State and the armed group is acting under the control of its own State, 'the fighting falls within the definition of an international armed conflict between two States. ${ }^{15}$ However, if the armed group is not acting on behalf of a government, in the absence of two States opposing each other, there is no international armed conflict. ... As regards the necessary degree of control of another State over an armed group acting on its behalf, the Trial Chamber has concluded that the 'overall control' test is the correct approach. $^{16}$

It furthermore held, in line with the PTC, that "international armed conflict' includes military occupation". ${ }^{17}$ The TC's statements call for two comments, one on the relevant test for establishing that an armed conflict has been 'internationalized' through indirect intervention by a state, and the other on the uneasy fit between the relational model of characterization and situations of occupation.

I will start with the former. The TC, just like the PTC, borrowed the "overall control" test from the Tadic Appeals Judgment, in which the ICTY Appeals Chamber famously parted ways with the International Court of Justice (ICJ). In the Nicaragua case, the ICJ had elaborated that for the purposes of attributing violations of international humanitarian law by the contras to the United States, the US would have had to exercise "effective control" over the operations of the contras. In other words, to establish US responsibility for the acts of private actors Nicaragua would have had to demonstrate "that the

\footnotetext{
${ }^{14}$ Ibid., para. 551.

${ }^{15}$ Quoting S. Vité, 'Typology of armed conflicts in international humanitarian law: legal concepts and actual situations', (2009) 91 International Review of the Red Cross 69, at 70-1, 90.

${ }^{16}$ Judgment, para. 541. Regarding the "overall control" test, the Trial Chamber relied on the Tadic jurisprudence, referring to Prosecutor v Dusko Tadic, Judgment, Appeals Chamber, IT-94-1-A, 1999, para. 137.

${ }^{17}$ Judgment, para. 542.
} 
United States directed or enforced the perpetration of the acts" in question. ${ }^{18}$ Considering this test to be incorrect, the Tadic Appeals Chamber opted for the looser "overall control" test, denying that specific control over the acts in question was necessary. ${ }^{19}$ The TC's decision would not have been surprising had the ICJ not rejected the ICTY's approach in its 2007 judgment in the Genocide case. ${ }^{20}$ This judgment was issued after the PTC had decided on the confirmation of charges in the Lubanga case ${ }^{21}$ and after all the ICTY judgments that the TC relied on in support of its conclusion had been issued. ${ }^{22}$ One could have expected the TC to at least consider the ICJ's opinion before blindly following the Tadic precedent.

To be sure, the ICJ did not reject the Tadic approach outright. Rather, the Court held that the "overall control" test "may well be applicable and suitable" when it comes to the distinction between international and non-international armed conflicts and merely rejected it for the purpose of attributing responsibility for internationally wrongful acts committed by non-governmental forces. ${ }^{23}$ Nevertheless, by emphasizing that the non-governmental forces need to act "on behalf of a State", the Lubanga TC did not engage with this distinction, thereby again conflating the two questions. Even if the distinction had been made, it would still have been necessary to show that the "overall control" test is indeed the correct test as regards the qualification of a conflict. ${ }^{24}$ In this context, opinions are divided as to whether issues of responsibility and the determination

${ }^{18}$ Military and Paramilitary Activities in and against Nicaragua (Nicaragua $v$ United States of America), Merits, Judgment, ICJ Reports 1986, at p. 63-4, para. 115.

${ }^{19}$ See generally Tadic Appeals Judgment, supra note 16, paras. 115-45. The Appeals Chamber described the content of the "overall control" test in para. 137: "[t]he control required by international law may be deemed to exist when a State (or, in the context of an armed conflict, the Party to the conflict) has a role in organising, coordinating or planning the military actions of the military group, in addition to financing, training and equipping or providing operational support to that group. Acts performed by the group or members thereof may be regarded as acts of de facto State organs regardless of any specific instruction by the controlling State concerning the commission of each of those acts."

${ }^{20}$ Application of the Convention on the Prevention and Punishment of the Crime of Genocide (Bosnia and Herzegovina $v$ Serbia and Montenegro), Merits, Judgment, ICJ Reports 2007, p.43, at 209-10, paras. 402-4.

${ }^{21}$ An attentive PTC might have noticed that the ICJ implicitly upheld the Nicaragua test in the context of the conflict in the Congo before the PTC issued its decision. See Case Concerning Armed Activities on the Territory of the Congo (Democratic Republic of the Congo v Uganda), Merits, Judgment, ICJ Reports 2005, p. 168, at 226, para. 160.

${ }^{22}$ See Judgment, note 1649.

${ }^{23}$ Genocide Case, supra note 20, para. 404.

${ }^{24}$ The ICJ left this question open; see ibid. 
of the character of the conflict can be distinguished at all ${ }^{25}$ and-if so-what the correct test for the latter question would be. ${ }^{26}$ Irrespective of what answer the TC would have given, considering that all cited authorities predate the ICJ's Genocide judgment, one would have expected the TC to show a minimum degree of awareness of this debate.

Moving on to the second question, the TC's relational theory may give rise to some unforeseen theoretical and practical problems. This stems from the fact that it is doubtful whether the TC's determination of the applicable law in a situation of occupation is (i) consistent and (ii) correct. With respect to consistency, the TC claimed that foreign occupation gives rise to an international armed conflict. At the same time, the TC seems to have suggested that in cases of occupation the relationship between an occupying state and resisting non-governmental forces will be governed by the law of non-international armed conflict. It stated that "[focusing] solely on the parties and the conflict relevant to the charges in this case, the Ugandan military occupation of Bunia airport does not change the legal nature of the conflict between the UPC/FPLC [and opposing] rebel groups since this conflict ... did not result in two States opposing each other, whether directly or indirectly". ${ }^{27}$ Thus, the TC appears to have contemplated that an occupation can in fact give rise either to an international armed conflict (when two state oppose each other) or to an armed conflict of a non-international character (where one of the warring party is a non-governmental group). The Trial Chamber should have made this clear-if this is indeed what it meant-rather than unequivocally stating that under occupation the law of international armed conflicts applies

${ }^{25}$ The ICJ was of the opinion that "logic does not require the same test to be adopted in resolving the two issues, which are very different in nature" (ibid., para. 405). For a skeptical comment, see E. La Haye, War Crimes in Internal Armed Conflict (CUP, 2008), at 17: "[i]f at first, the laws on state responsibility do not seem to be the adequate tool to determine the nature of an armed conflict, they nonetheless allow for a determination of the international status of the entities party to an armed conflict. If the acts of an armed group can be imputed to a foreign state, the latter should surely be seen as a de facto organ of that foreign state and the conflict would therefore be an international one. The international legal status of each party to the conflict, state officials, de facto organ of a state or armed group acting independently of the orders of a state for example, constitutes the correct criteria establishing the character of an armed conflict." See also G. Werle, Principles of International Criminal Law (TMC Asser Press, 2009), at 371: "[i]f acts by non-state organizations or even individuals cannot be imputed to a state, there is no international armed conflict".

${ }^{26}$ Cf. D. Akande, 'Classification of Armed Conflicts: Relevant Legal Concepts', in E. Wilmshurst (ed), International Law and the Classification of Conflicts (OUP, 2012) (forthcoming; advance copy on file with the author, final page numbering may differ), at 38-40.

${ }^{27}$ Judgment, para. 565. 
and then implicitly correcting itself.

Whether the TC's approach is correct as a matter of law is a different matter. As Dapo Akande points out, there are good reasons for holding that the relations between a non-governmental armed group and an occupying state should be governed by the law of international armed conflict. ${ }^{28}$ This approach, even though well-founded, sits uneasily with the TC's general relational theory. To illustrate this, recall the TC's statement that an armed conflict between a state and a non-governmental group in a neighboring state not acting on behalf of that state is non-international in character. The logical consequence of combining this general relational approach with Dapo Akande's proposal regarding situations of occupation would be that forces of an invading state that come to be opposed by a non-governmental group are bound by the law of non-international armed conflict only until they have established sufficient control to be considered an occupying power. Once such control is established, the nature of the conflict would change and become regulated by the law of international armed conflict. However, under a relational model of conflict characterization, it makes little sense to condition the applicable legal regime on factors that are unrelated to the actual relationship of the warring parties. The logical solution would thus appear altogether to abandon the relational approach in cases of hostilities between an invading/occupying state and non-governmental forces.

Such a solution is indeed proposed by Dapo Akande, who suggests that every case of invasion by one state of the territory of another state should be governed by the law of international armed conflict, even if the sole objective of the invasion is to fight non-governmental forces. ${ }^{29}$ The non-governmental fighters would, under this construction, be treated as civilians directly participating in hostilities. ${ }^{30}$ As a consequence, this approach would seem to dispense with the requirement that armed groups must reach a certain degree of organization in order to be considered a party to an armed conflict. While this approach may not be problematic from a legal perspective, it would seem to factually mischaracterize the actual armed conflict between a state and a non-governmental group. But more importantly, it would call the TC's more general relational theory of conflict characterization into question.

In the end, the TC decided that the relevant acts in the Lubanga case had all been committed in the context of a conflict between non-governmental armed

\footnotetext{
${ }^{28}$ Cf. Akande, supra note 26, at 19-21.

${ }^{29} \mathrm{Ibid}$., at 55-60.

${ }^{30}$ Ibid., at 60-1.
} 
groups and that the indirect involvement of Uganda, Rwanda and the DRC was either insufficiently substantial or irrelevant. ${ }^{31}$ On this basis, the Chamber invoked its power under Regulation 55 of the Regulations of the Court ${ }^{32}$ and re-characterized the facts charged by the Prosecutor as relating only to Article 8(2)(e)(vii), thereby reversing the PTC's decision in this respect. Given this back-and-forth, existing concerns about the propriety of allowing the PTCs and TCs to unilaterally change the legal characterization of facts, stemming from the doubtful legality of this practice under the Statute and the shift of power from the Prosecutor to the Chambers that it implies, will not be muted. ${ }^{33}$

\section{The crimes of enlisting, conscripting and using child soldiers}

With respect to substantive crimes, the Lubanga TC only had to deal with the war crimes of enlisting, conscripting and using child soldiers. In interpreting the Rome Statute's provisions, the TC in Lubanga found that "[a]lthough the decisions of other international courts and tribunals are not part of the directly applicable law under Article 21 of the Statute", the similarity between the provisions of the ICC's and the Special Court for Sierra Leone's (SCSL) Statutes regarding child soldiers meant that " $[\mathrm{t}]$ he SCSL's case law ... potentially assists in the interpretation of the relevant provisions of the Rome Statute" ${ }^{34}$ However, in setting out the elements of the crime, the TC eventually went beyond the SCSL's-and for that matter, the PTC's-jurisprudence. Before the TC's novel interpretation is discussed, however, some attention must be paid to its decision not to address the (i) differences between the provisions applying in international and non-international armed conflicts and (ii) the controversial issue of sexual violence.

\footnotetext{
${ }^{31}$ Judgment, paras. 553-567.

${ }^{32}$ Regulations of the Court, ICC Doc. ICC-DB/01-02-07, 18 December 2007. Paragraph 1 of Regulation 55 provides that "[i]n its decision under Article 74, the Chamber may change the legal characterisation of facts to accord with the crimes under Articles 6, 7 or 8, or to accord with the form of participation of the accused under Articles 25 and 28, without exceeding the facts and circumstances described in the charges and any amendments to the charges."

${ }^{33}$ See in particular D. Jacobs, 'A Shifting Scale of Power: Who is in Charge of the Charges at the International Criminal Court?', in W. Schabas et al. (eds), The Ashgate Research Companion to International Criminal Law: Critical Perspectives (Ashgate, 2012) (forthcoming) (available at SSRN, ID: 1971821).

${ }^{34}$ Judgment, para. 603.
} 
With respect to the first point, the PTC's decision that some of the acts charged had been committed in the context of an international armed conflict ${ }^{35}$ forced it to interpret the difference between the two provisions in question, one prohibiting the enlistment or conscription of child soldiers into the "national armed forces", the other referring to "armed forces or groups" in general. ${ }^{36}$ The PTC eventually decided, on the basis of some strongly teleological reasoning, that 'the term 'national armed forces' is not limited to the armed forces of a State", ${ }^{37}$ an interpretation that effectively erases the difference in the wording of the two provisions. The TC, by contrast, having arrived at the conclusion that all relevant acts took place in the context of a non-international armed conflict, considered it "unnecessary to interpret or discuss Article 8(2)(b)(xxvi)," whilst noting the "significant difference in wording". ${ }^{38}$ The TC's emphasis on the "significant difference in wording" may be seen as subtle criticism of the PTC's interpretation, which amounted to an outright denial that any real difference existed between the two provisions.

The TC's decision not to address this question leaves the issue open, a fact that is severely criticized by Judge Odio Benito in her separate and dissenting opinion. ${ }^{39}$ She argues that "the discussion on the concept of 'national armed forces' is required as this is a live issue in the present case". ${ }^{40}$ She leaves no doubt that, in her opinion, the difference in wording should be ignored. ${ }^{41}$

Whether the liberal interpretation promoted by the PTC and Judge Odio Benito will eventually prevail remains to be seen. The TC's hesitation in this regard can, however, be read to indicate that the issue is not as simple as the PTC and Judge Odio Benito portrayed it. The rules on effective treaty interpretation ${ }^{42}$ would appear to require that some meaning be attached to the different wording. One possible solution might emerge from the TC's approach as regards the characterization of armed conflicts. Given the TC's endorsement of a relational model of armed conflict characterization and the acceptance that

\footnotetext{
${ }^{35}$ Lubanga Confirmation Decision, para. 220.

${ }^{36}$ Art. 8(2)(b)(xxvi) and 8(2)(e)(vii), Rome Statute, supra, note 4.

${ }^{37}$ Lubanga Confirmation Decision, para. 285. See generally ibid., paras. 268-84.

${ }^{38}$ Judgment, para. 568.

${ }^{39}$ Prosecutor v Thomas Lubanga Dyilo, Judgment Pursuant to Article 74 of the Statute, Trial Chamber I, ICC-01/04-01/06, 2012 (Judge Odio Benito, Separate and Dissenting Opinion) (hereinafter 'Opinion Odio Benito').

${ }^{40}$ Ibid., para. 12.

${ }^{41}$ Ibid., para. 14.

${ }^{42}$ The ICC Appeals Chamber has held that the Rome Statute should be interpreted according to the Vienna Convention on the Law of Treaties. See references to the relevant Appeals Chamber jurisprudence in Judgment, para. 601 and fn. 1766.
} 
an international armed conflict requires a confrontation between two states (including via groups fighting on their "behalf"), it is doubtful whether the ICC will ever find a non-governmental group to be involved in an international armed conflict. However, once the TC establishes that such a group is under the "overall control" of a state (provided that this test remains applicable), likening this group to "national armed forces" is more easily done-especially given that the TC appears to have endorsed the "overall control" test as a test of attribution, rather than as one only relating to the character of the conflict-and does not require negating the difference between the wording of Articles 8(2)(b)(xxvi) and $8(2)(e)($ vii) altogether.

The second issue that the Chamber chose not to address is whether acts of sexual violence can be counted as "using [children] to participate actively in hostilities", as some of the victims had argued during the trial. ${ }^{43}$ Basing its arguments on the fact that the Prosecution had not pleaded acts of sexual violence and that they were not included in the confirmation of charges decision, the Chamber decided not to pronounce on the question of whether they fall under the definition of the crime. ${ }^{44}$ Judge Odio Benito again strongly dissented and argued that the Chamber should have clarified the law; in her opinion, by not doing so "the Majority of the Chamber is making this critical aspect of the crime invisible." 45 Whatever the merits of the claim that sexual violence can constitute "using [children] to participate actively in hostilities", the disagreement between Judge Odio Benito and the majority appears to express a more profound divergence with respect to the judicial function of the TC. Indeed, Judge Odio Benito stated openly that she "deem[s] that the Majority of the Chamber addresses only one purpose of the ICC trial proceedings: to decide on the guilt or innocence of an accused person", while in her opinion "ICC trial proceedings should also attend to the harm suffered by the victims as a result of the crimes within the jurisdiction of the Court". ${ }^{46}$ One might add to this a third function, which is implicit in Judge Odio Benito's criticism regarding sexual violence, namely that the Court should state the law where there are policy reasons to do so, even if this is unnecessary to decide the case at hand. Regardless of which position one prefers in this debate, the disagreement suggests that the ICC has yet to settle on a firm conception of its own judicial function.

Moving on to what the Chamber did pronounce itself upon, the most

\footnotetext{
${ }^{43}$ Judgment, paras. 629-30.

${ }^{44}$ Ibid., para 629.

${ }^{45}$ Opinion Odio Benito, para. 16.

${ }^{46}$ Ibid., para. 8.
} 
interesting - and likely controversial-section of the judgment deals with the definition of "using [children] to participate actively in hostilities". In a first step, the Chamber distinguished the notion of active participation in hostilities from the more common international humanitarian law notion of direct participation, a move that has already given rise to criticism. ${ }^{47}$ The Chamber stated that:

Those who participate actively in hostilities include a wide range of individuals, from those on the front line (who participate directly) through to the boys or girls who are involved in a myriad of roles that support the combatants. All of these activities, which cover either direct or indirect participation, have an underlying common feature: the child concerned is, at the very least, a potential target. The decisive factor, therefore, in deciding if an 'indirect' role is to be treated as active participation in hostilities is whether the support provided by the child to the combatants exposed him or her to real danger as a potential target. In the judgment of the Chamber these combined factors-the child's support and this level of consequential risk-mean that although absent from the immediate scene of the hostilities, the individual was nonetheless actively involved in them. Given the different types of roles that may be performed by children used by armed groups, the Chamber's determination of whether a particular activity constitutes 'active participation' can only be made on a case-by-case basis. ${ }^{48}$

The determination that a wide variety of activities can constitute active participation is not particularly innovative. The Preparatory Committee, the PTC and the SCSL had all reached similar conclusions. ${ }^{49}$ However, the TC departed from these precedents in two ways. First, the Preparatory Committee

\footnotetext{
${ }^{47}$ N. Urban, 'Direct and Active Participation in Hostilities: The Unintended Consequences of the ICC's decision in Lubanga', 2012, EJIL: Talk (11 April 2012); see also C. Aptel, 'Lubanga Decision Roundtable: The Participation of Children in Hostilities', 2012, Opinio Juris (18 March 2012).

${ }^{48}$ Judgment, para. 628 , footnotes omitted.

${ }^{49}$ Draft Statute for the International Criminal Court, Report of the Preparatory Committee on the Establishment of an International Criminal Court, UN Doc. A/Conf.183/2/Add.1, at 21, fn. 12; Lubanga Confirmation Decision, para. 261; Prosecutor v Alex Tamba Brima, Brima Bazzy Kamara, and Santigie Borbor Kanu, Judgment, SCSL-04-16-T, 2007, (hereinafter 'AFRC Judgment'), para. 737.
} 
and the PTC had both made clear that the provision excludes activities that are "clearly unrelated to hostilities" and named as examples of such activities "food deliveries to an airbase or the use as domestic staff in married officers' quarters". ${ }^{50}$ The TC failed to endorse these limitations, thereby casting some doubt on whether there exists any minimum degree to which a particular activity needs to be connected to the conduct of hostilities. This move appears to be the consequence of a more profound departure from existing precedent. In effect, the TC seems to have altogether abandoned the idea that some connection to the conduct of hostilities is required, at least as regards forms of "indirect participation" (i.e. not fighting on the front line). Instead, the idea of contribution, at the root of both the concepts of direct and active participation as they had been hitherto understood, ${ }^{51}$ was replaced with that of risk. ${ }^{52}$ While the Chamber, in the above quoted passage, first held that a combination of the child's contribution and the consequential risk is decisive, it later more blatantly stated that "[t]he decisive factor in deciding whether an indirect role is to be treated as active participation in hostilities is whether the support provided by the child to the combatants exposed him or her to real danger by becoming a target". ${ }^{53}$ In effect, the TC replaced the notion of "participation in hostilities" with the notion of "exposure to danger". ${ }^{4}$

In light of its wide interpretation of the phrase "participating actively in hostilities", it is not surprising that the TC did not endorse the Preparatory Committee's view that Article 8(2)(b)(xxvi) and Article 8(2)(e)(vii) would exclude "activities clearly unrelated to hostilities". As we saw, the TC considered the connection of an activity to the hostilities to be irrelevant, and focused only on

\footnotetext{
${ }^{50}$ Lubanga Confirmation Decision, para. 262; Prepcom, ibid., at 21, note 12.

${ }^{51} \mathrm{~J}$. Pictet et al., Commentary on the Additional Protocols of 8 June 1977 to the Geneva Conventions of 12 August 1949 (Nijhoff, 1987), para. 1944; N. Melzer, Interpretive Guidance on the Notion of Direct Participation in Hostilities under International Humanitarian Law (ICRC, 2009), at 46 et seq.; Lubanga Confirmation Decision, para. 262, Prepcom, supra note 49, at 21, note 12; AFRC Judgment, supra note 49, paras. 736-7; A. Smith, 'Child Soldiers (Recruitment and Use in Armed Conflict)', in A. Cassese (ed), Oxford Companion to International Criminal Law (OUP, 2009), at 262. Note that the SCSL already mentions the issue of risk faced by the children, but does not seem to attach much weight to it.

${ }^{52}$ In support, the Chamber cites a single piece of German doctrine (at note 1804): G. Palomino Suárez, Kindersoldaten im Völkerstrafrecht (BWV, 2009), at 166-8.

${ }^{53}$ Judgment, para. 820.

${ }^{54}$ In her separate opinion, Judge Odio Benito went even further by apparently pleading to also include the risk that arises from the conduct of the armed groups that use the children in the first place (Opinion Odio Bentio, paras. 18-19). Thus, the relevant category would be exposure to danger either from attack by the opposing armed forces or from the conduct of the "own" armed forces.
} 
exposure to risk. Clearly, delivering food to an airbase may expose a child to danger of attack (considering that an air base would likely constitute a military target), and the incorporation of children to the domestic staff in married officers' quarters may expose them to some form of abuse or risk. Such a wide interpretation, relying heavily on teleological reasoning, is not unsustainable, but sits uneasily with the actual wording of the provision: "using [children] to participate actively in hostilities". It does not take much foresight to predict that the last word on this matter has not yet been spoken.

\section{The mental element of criminal liability}

After establishing that the crimes of enlisting, conscripting and using child soldiers had been committed, the TC went on to consider Lubanga's individual criminal responsibility. The Prosecution had charged Lubanga under Article 25(3)(a) of the Statute as a co-perpetrator. ${ }^{55}$ In its confirmation of charges decision, the PTC had found that co-perpetration under this provision corresponded to Claus Roxin's "control theory", rather than the ICTY's Joint Criminal Enterprise (JCE) concept. ${ }^{56}$ The most significant distinction between the two lies in the fact that under the JCE doctrine, any contribution to the common plan satisfies the actus reus requirement, ${ }^{57}$ while the control theory demands an essential contribution, i.e. one without which the crime would not have been committed. ${ }^{58}$ The majority of the TC accepted the PTC's approach and embraced the control theory. ${ }^{59}$ Judge Fulford dissented, arguing that an essential contribution is not required under the Rome Statute. ${ }^{60}$ While the TC's endorse-

\footnotetext{
${ }^{55}$ Under Article 25(3)(a), a person is criminally responsible if he or she "[c]ommits such a crime, whether as an individual, jointly with another or through another person, regardless of whether that other person is criminally responsible".

${ }^{56}$ See Lubanga Confirmation Decision, paras. 326-341.

${ }^{57}$ See Prosecutor v Miroslav Kvocka et al., Judgment, Appeals Chamber, IT-98-30/1-A, 2005, paras. 97, 421.

${ }^{58}$ Lubanga Confirmation Decision, paras. 334-5, 346-7. See also Judgment, paras. 921-2.

${ }^{59}$ Judgment, paras. 996-9.

${ }^{60}$ Prosecutor v Thomas Lubanga Dyilo, Judgment Pursuant to Article 74 of the Statute, Trial Chamber I, ICC-01/04-01/06, 2012 (Judge Fulford, Separate and Dissenting Opinion) (hereinafter "Opinion Fulford"), paras. 9-18. The disagreement between the majority and Judge Fulford also reveals that uncertainty exists not only as to the correct construction of Article 25(3)(a), but also as regards the overall scheme of Article 25(3), particularly with respect to the delineation between the various modes of responsibility. On the topic, see J. Ohlin, 'Lubanga Decision Roundtable: Lubanga and the Control Theory',2012, Opinio Juris (15 March 2012); K.-J. Heller, 'Lubanga Decision Roundtable: More on Co-Perpetration', 2012, Opinio
} 
ment of the control theory and Judge Fulford's dissent are certainly important, I will focus on another development, namely the TC's analysis of the mens rea requirement in cases of co-perpetration and possibly beyond.

The starting point regarding the mens rea for co-perpetration is an objective element of this concept, namely the requirement of "the existence of an agreement or common plan between two or more persons that, if implemented, will result in the commission of a crime". ${ }^{61}$ The common plan need not, in itself, be criminal, but must involve a "critical element of criminality". 62 The PTC and the TC disagreed as to how this element of criminality would be satisfied. The PTC was of the opinion that dolus eventualis would suffice to supply the element of criminality, distinguishing between cases of substantial risk and those of low risk. ${ }^{63}$ The TC, on the other hand, held that the element of criminality is present where the common plan's "implementation embodied a sufficient risk that, if events follow the ordinary course, a crime will be committed." ${ }^{4}$ In translating this standard into a general mens rea requirement under Article 30 of the Statute, the TC first rejected the PTC's endorsement of dolus eventualis, thereby following PTC II's confirmation of charges decision in the Bemba case. ${ }^{65}$

Juris (16 March 2012). See generally on this issue: J. Ohlin, 'Joint Criminal Confusion', (2009) 12 New Criminal Law Review 406; K. Ambos, 'Article 25-Individual Criminal Responsibility', in O. Triffterer (ed), Commentary on the Rome Statute of the International Criminal Court: Observers' Notes, Article by Article (Beck/Hart, 2008).

${ }^{61}$ Judgment, para. 1006.

${ }^{62}$ Ibid., para. 984. The PTC spoke only of an "element of criminality" (Lubanga Confirmation Decision, para. 344). Holding that the common plan must not, in itself, be criminal might mark a further difference between the ICC's notion of co-perpetration and the customary concept of JCE. In the AFRC Judgment, supra note 49, the SCSL TC held that "[e]ven though the contribution to a joint criminal enterprise need not be criminal in nature, the purpose must be inherently criminal and the perpetrators, including the accused, must have a common state of mind, namely the state of mind that the statutory crime(s) forming part of the objective should be carried out" (para. 73, footnotes omitted). The ICTY jurisprudence is not entirely clear on this matter, requiring only that "[ $t]$ he existence of a common plan, design or purpose which amounts to or involves the commission of a crime provided for in the Statute" (Tadic Appeals Judgment, supra note 16, para. 227). Nevertheless, when discussing the required mens rea for JCE III liability, the Tadic Appeals Chamber required the accused to have "the intention to take part in a joint criminal enterprise and to further-individually and jointly-the criminal purposes of that enterprise" (ibid., para. 220, emphasis added). See also K. Gustafson, 'Joint Criminal Enterprise', in A. Cassese (ed), Oxford Companion to International Criminal Law (OUP, 2009), at 394, who interprets the Tadic pronouncement to mean that "the plan must be inherently criminal".

${ }^{63}$ Lubanga Confirmation Decision, paras. 344, 352-3.

${ }^{64}$ Judgment, para. 984.

${ }^{65}$ Ibid., para. 1011, referring to Prosecutorv Jean-Pierre Bemba Gombo, Decision Pursuant to Article 
However, in the very next paragraph of the judgment, some form of dolus eventualis or recklessness seems to slip back in:

In the view of the Majority of the Chamber, the 'awareness that a consequence will occur in the ordinary course of events' means that the participants anticipate, based on their knowledge of how events ordinarily develop, that the consequence will occur in the future. This prognosis involves consideration of the concepts of 'possibility' and 'probability', which are inherent to the notions of 'risk' and 'danger'. Risk is defined as 'danger, (exposure to) the possibility of loss, injury or other adverse circumstance.' The co-perpetrators only 'know' the consequences of their conduct once they have occurred. At the time the co-perpetrators agree on a common plan and throughout its implementation, they must know the existence of a risk that the consequence will occur. As to the degree of risk, and pursuant to the wording of Article 30, it must be no less than awareness on the part of the co-perpetrator that the consequence 'will occur in the ordinary course of events'. A low risk will not be sufficient. ${ }^{66}$

This elaboration of risk, criticized by Judge Fulford as "unhelpful", ${ }^{67}$ relates to the often fluid border between dolus directus of the second degree ${ }^{68}$ and dolus eventualis. Whether an accused is aware that a consequence "will occur in the ordinary course of events" is difficult to assess. As a matter of fact, there are two separate probabilities (and the accused's knowledge thereof) at play here: the first relates to the probability with which the "ordinary" course of events takes place. The second one relates to the probability with which the crime actually follows from that ordinary course of events. The probability that the crime will occur is then the product of these two separate probabilities.

61(7)(a) and (b) of the Rome Statute on the Charges of the Prosecutor Against Jean-Pierre Bemba Gombo, Pre-Trial Chamber II, ICC-01/05-01/08, 2009, paras. 364-9. Academic opinion is divided as to whether Art. 30 includes dolus eventualis (cf. M. Badar, 'The Mental Element in the Rome Statute of the International Criminal Court: A Commentary from a Comparative Criminal Law Perspective', (2008) 19 Criminal Law Forum 473, at 487). For explicit support of the PTC's approach see Werle, supra note 25, at 153-5.

${ }^{66}$ Judgment, para. 1012, footnotes omitted.

${ }^{67}$ Opinion Fulford, para. 15.

${ }^{68}$ The PTC defined this type of intent being present in "situations in which the suspect, without having the concrete intent to bring about the objective elements of the crime, is aware that such elements will be the necessary outcome of his or her actions or omissions" (Lubanga Confirmation Decision, para. 352). 
It is this overall probability that the TC seems to be concerned with. But what level of probability is required, what degree of risk is "sufficient"? 69 The only guidance the majority provides is to repeat that the suspect must be aware that the "consequence will occur in the ordinary course of events" and that low risk does not suffice. In the end, the majority comes full circle, having set out to illuminate what "awareness that a consequence will occur in the ordinary course of events" means and concluding that it means being aware that a crime "will occur in the ordinary course of events". That being so, Judge Fulford is correct in stating that this discussion eventually turned out to be unhelpful, if not exactly for the reasons he mentioned. ${ }^{70}$

What is more, the TC seems to have departed from the previously endorsed PTC II decision in Bemba, thereby creating further uncertainty as to the correct legal standard that applies in these situations. In Bemba the PTC held that "the suspect could not be said to have intended to commit any of the crimes charged, unless the evidence shows that he was at least aware that, in the ordinary course of events, the occurrence of such crimes was a virtually certain consequence of the implementation of the common plan". ${ }^{11}$ Thus, the Bemba PTC separates the two probabilities, stating that the second one needs to amount to "virtual certainty", yet not providing any guidance on the first one. While the Bemba PTC was thus not much more precise than the TC in Lubanga with respect to the overall probability requirement, it at least simplified the equation by fixing one of the two variables. By not following this approach, the Lubanga TC cast some doubt on it.

Another point that deserves some attention is how this conception of co-perpetration relates to JCE III liability under the jurisprudence of the ICTY. JCE III liability attaches criminal responsibility to persons who share a common purpose where a crime committed fell outside the common purpose but was

${ }^{69}$ A. Eser, 'Individual Criminal Responsibility', in A. Cassese et al. (eds), The Rome Statute of the International Criminal Court (OUP, 2002), at 792: "in Article 30 requiring 'intent and knowledge' for the commission of a crime (paragraph 1), and in its definition of knowledge as awareness of the occurrence of a consequence 'in the ordinary course of events' (paragraph 3), it is at least a question of fact, if not of law, as to when an 'excessive' act can be considered part of the 'ordinary course' of events." Badar, supra note 65, at 485: "the phrase 'aware that it will occur in the ordinary course of events' is subject to different interpretations. Does it require that the perpetrator foresees the occurrence of the consequence as certain? Or whether mere awareness of the probable occurrence of the consequence is sufficient?" See also Weigend, supra note 9, at 482 , referring to the required degree of risk as "an open question".

${ }^{70}$ Judge Fulford held that no particular clarification of the mental requirement is necessary, as he considered the words used to be sufficiently clear (Opinion Fulford, para. 15).

${ }^{71}$ Bemba Confirmation Decision, supra note 65, para. 369 (emphasis added). 
the "natural and foreseeable" consequence of its implementation. ${ }^{72}$ How is a consequence "occurring in the ordinary course of events" different from a "natural and foreseeable" consequence? As regards the precise degree to which the accused must have foreseen the occurrence of such a crime, the ICTY Appeals Chamber held that "[p]lotted on a spectrum of likelihood, the JCE III mens rea standard does not require an understanding that a deviatory crime would probably be committed; it does, however, require that the possibility a crime could be committed is sufficiently substantial as to be foreseeable to an accused" and added that "implausibly remote scenarios" do not suffice. ${ }^{73}$ As indicated above, the Lubanga TC required a "sufficient risk" and held that "low risk will not be sufficient" ${ }^{\text {" }}$ The question then arises of whether these standards are similar or whether they require different probabilities. Is the difference, if any, one of degree or one of kind?

These questions matter for two reasons: first, the concept of JCE III has often been criticized for "overreaching" the principle of personal guilt. ${ }^{75}$ The same criticism might be leveled against the TC's interpretation of Article 25(3)(a). Secondly, and more importantly, this latter reading of co-perpetration might even go significantly further than JCE III liability. JCE III liability presupposes intent to commit the crimes falling within the common purpose. ${ }^{76}$ Co-perpetration, on the other hand, does not demand a criminal purpose at all, meaning that a person might be held to be a co-perpetrator even if she or he pursued an entirely innocent purpose that carried a "sufficient risk" that a crime would occur as a consequence. Granted, co-perpetration, as defined by the majority, requires a higher degree of contribution than JCE liability. However, the TC held that "the accused [must provide] an essential contribution to the

\footnotetext{
${ }^{72}$ See Kvocka Appeals Judgment, supra note 56, para. 83.

${ }^{73}$ Prosecutor $v$ Radovan Karadzic, Decision on Prosecution Motion Appealing Trial Chamber's Decision on JCE III Foreseeability, Appeals Chamber, IT-95-5/18-AR72.4, 2009, para. 18.

${ }^{74}$ Judgment, para. 1012.

${ }^{75}$ Cf. Cryer, supra note 7, at 373.

${ }^{76}$ See Tadic Appeal Judgment, supra note 16, para. 228: "[w]ith regard to the third category, what is required is the intention to participate in and further the criminal activity or the criminal purpose of a group and to contribute to the joint criminal enterprise or in any event to the commission of a crime by the group. In addition, responsibility for a crime other than the one agreed upon in the common plan arises only if, under the circumstances of the case, (i) it was foreseeable that such a crime might be perpetrated by one or other members of the group and (ii) the accused willingly took that risk." The same is true if the direct perpetrator of the deviatory crime was not himself a member of the JCE, but where his commission of deviatory crime was foreseeable to the accused JCE member (see Prosecutorv Radoslav Brdanin, Judgment, Appeal Chamber, IT-99-36-A, 2007, para. 411).
} 
common plan that resulted in the commission of the relevant crime", ${ }^{77}$ that is, the contribution is not measured against the crime but against the potentially innocent purpose. The "essential contribution" requirement therefore does not cure the potential overreach. Taken to the extreme, the combination of not requiring an inherently criminal purpose and having a rather unclear conception of the required risk might result in the adoption of a very broad doctrine of co-perpetration.

\section{The participation of victims as witnesses}

Being the first trial to have been concluded, the Lubanga trial was also the first chance to see how the ICC's provisions on victims' participation would work in practice. While most of these matters were the subject of decisions in the preliminary stages of the trial, ${ }^{78}$ one complex question has surfaced only recently. During the trial, it emerged that a number of persons who had been granted the right to participate in the proceedings as victims and who had also testified as witnesses had given unreliable evidence.

The TC thus faced the question of how to deal with victims that had been allowed to participate on the basis of prima facie evidence that did not withstand closer scrutiny. The majority, without much explanation, considered that "if the Chamber, on investigation, concludes that its original prima facie evaluation was incorrect, it should amend any earlier order as to participation, to the extent necessary" and that "[i]t would be unsustainable to allow victims to continue participating if a more detailed understanding of the evidence has demonstrated they no longer meet the relevant criteria". ${ }^{79}$ On this basis, the majority decided to withdraw the right to participate from five witnesses that had proved unreliable and from the father of one of these witnesses. ${ }^{80}$

While the majority's approach appears reasonable at first sight, Judge Odio Benito raised some important points that put the propriety of the majority's decision into question. Judge Odio Bentio criticized the majority both on the basis of its conclusions as regards the individual victims concerned and with respect to the general approach it adopted. As far as the latter is concerned, she pointed out that "it is unfair and discriminatory to impose upon individuals with dual status a higher evidentiary threshold (beyond reasonable doubt)

\footnotetext{
${ }^{77}$ Judgment, para. 1006.

${ }^{78}$ See the summary at Judgment, para. 14.

${ }^{79}$ Judgment, para. 484.

${ }^{80} \mathrm{Ibid}$.
} 
as regards their victim's status, while all other victims participating in the proceedings have not been subject to thorough examination by the parties and the Chamber". 1

This is a valid point that highlights an underlying dilemma: it does not seem fair to allow dual status witnesses to maintain their victims' rights if they have proved to be unreliable; yet it is also not fair to apply different evidentiary standards to victims that testify and to those that do not. On the one hand, the latter approach may lead to reluctance of recognized victims to testify in the trial. It may also cause problems when the Prosecution must choose among many victim-witnesses which ones to call to testify. On the other hand, allowing even victims whose credibility has been undermined to continue to participate is clearly problematic, particularly at the reparations stage. As Judge Odio Benito pointed out, in this context "the Trial Chamber [will have] to determine the criteria utilized in determining [the excluded victims'] final status". ${ }^{82}$ It will be very interesting to see if and how the TC tackles this problem at the reparations stage. Simply excluding the incredible victims from that stage from the outset would not be a convincing solution. However, given the majority's present decision, this is how the TC is likely to proceed.

\section{Review of the pre-trial chamber's legal findings}

The final issue I want to comment on is the question of the review by the TC of legal determinations made by the PTC, raised by Judge Fulford in his individual opinion. Arguably, this issue only arises because the PTCs have taken it upon themselves to issue lengthy confirmation of charges decisions that contain elaborate reasoning on the law. There is room to argue that in fulfilling its function, namely to "determine whether there is sufficient evidence to establish substantial grounds to believe that the person committed each of the crimes charged", ${ }^{83}$ the PTC does not need to settle on a definite interpretation of a law if the presented evidence would suffice under multiple possible interpretations. However this may be, the question of the extent to which the TC is competent to revisit issues of law decided by the PTC in the confirmation of charges decision is relevant.

\footnotetext{
${ }^{81}$ Opinion Odio Benito, para. 13.

${ }^{82}$ Ibid., para. 35.

${ }^{83}$ Art. 61(7), Rome Statute, supra, note 4.
} 
Judge Fulford suggested that the TC may be bound to stick to the law set out by the PTC if departing from it could prejudice the accused. In his dissent regarding the contours of co-perpetration, he wrote that:

I wish to make clear at the outset that I agree with my colleagues that the tests described in paragraphs 1013 and 1018 of the Judgment are to be applied at this stage of this case. Focusing on the requirements of Article 25(3)(a) of the Statute, with minor modifications to ensure compliance with the Statute, the test described at paragraph 1018 mirrors the approach of the Pre-Trial Chamber in the Decision on the Confirmation of Charges, which established (certainly in this context) the principles of law on which the trial has been prosecuted and defended. No substantive warning has been given to the parties that the Chamber may apply a different test, and as a matter of fairness it would be wrong at this late stage to modify the legal framework of the case. In short, it would be unjust to the present accused to apply a different, and arguably lesser, test. $^{84}$

One can only speculate what would have happened if the majority had shared Judge Fulford's criticism of the co-perpetration doctrine as set out by the PTC. Following Judge Fulford's logic, the Chamber would have had to apply the PTC's law even if it had found this to be erroneous. This raises a host of further questions: ${ }^{85}$ would there be some form of safeguard against upholding even manifest or gross errors of law or some rule allowing minor changes? ${ }^{86}$ Would the reasoning apply with the same force if the Prosecution were at a disadvantage by virtue of a decision of the TC overruling the PTC? Would this approach apply to all questions of law decided by the PTC or would some be excluded? ${ }^{87}$

\footnotetext{
${ }^{84}$ Opinion Fulford, para. 2.

${ }^{85}$ Cf. also Ohlin (2012), supra note 60.

${ }^{86}$ Judge Fulford does not seem to object to "minor modifications to ensure compliance with the Statute", Opinion Fulford, para. 2.

${ }^{87}$ That the latter may be the case is suggested by the fact that the TC apparently had no problem with overturning the PTC's re-characterization of facts as regards the character of the armed conflict. As Judge Odio Benito pointed out, "the defense has from start to finish argued that the armed conflict in question is an international armed conflict" (Opinion Odio Benito, para. 12). Did not the decision of the TC to reverse the PTC's re-characterization of facts negatively impact upon the defense in exactly the way that Judge Fulford feared? It might be argued that this particular case was different for two reasons: first, the existence of Regulation 55 may
} 
Another area that would be affected by Judge Fulford's approach is that of appeals against confirmation of charges decisions. First, if it were accepted that that TC cannot change the "law of the case" as set out by the PTC, this would mean that most appeals against a question of law in the confirmation of charges decision would appear to satisfy the standard required for leave to appeal to be granted. As confirmation of charges decisions cannot be appealed automatically, a particular issue under appeal must be such that "a. it would significantly affect (i) both the fair and expeditious conduct of the proceedings or (ii) the outcome of the trial, and b. in the opinion of the Pre-Trial or Trial Chamber, its immediate resolution by the Appeals Chamber may materially advance the proceedings" ${ }^{88}$ If the TC is stripped of the power to depart from the PTC's statements of the law, most appeals against such statements are likely to fulfill the above conditions.

Finally, what effect would this reasoning have in the context of an appeal against a judgment? The Appeals Chamber, of course, has the power to consider errors of law and can either reverse, amend or remand the appealed judgment. ${ }^{89}$ Clearly, the Appeals Chamber would not be bound to uphold the PTC's law. However, if reversing an error of law on appeal and amending the conviction is not considered to violate the rights of the accused to a fair trial, why would doing so at the trial stage have a different effect? When taken to the extreme, Judge Fulford's approach would seriously curtail the TC's power to consider questions of law, a rather fundamental task of a TC. It is interesting to note that the Chamber-including Judge Fulford-did not seem to have had any problems in widening the definition of active participation in hostilities beyond that set out by the PTC, even if this move does not appear to have had a significant impact in this particular case. Whether Judge Fulford's concerns will be heeded in the ICC's future practice remains to be seen.

be taken as sufficient warning to both parties that a re-characterization could occur, so that neither party could claim reliance on the PTC's pronouncement. Secondly, in rejecting both the Defense and the Prosecution's request to appeal against this ruling, the PTC pointed out that "there is nothing to prevent the Prosecution or the Defence from requesting that the Trial Chamber reconsider the legal characterisation of the facts described in the charges against Thomas Lubanga Dyilo and as confirmed by the Chamber" (Prosecutor $v$ Thomas Lubanga Dyilo, Decision on the Prosecution and Defence applications for leave to appeal the Decision on the confirmation of charges, Pre-Trial Chamber I, IT-01/04-01/06, 2007, para. 44). This may be taken to constitute additional notice that a further change could occur.

${ }^{88}$ Lubanga Decision on Leave to Appeal Confirmation Decision, supra note 87, para. 21.

${ }^{89}$ Art. 81(1) and 83(2), Rome Statute, supra, note 4. 


\section{Concluding remarks}

Apart from the joy of finally having a trial judgment delivered by an ICC Trial Chamber, what are we to make of the Lubanga judgment? Having considered some of the legal issues and the controversies surrounding them, two conclusions may be drawn.

First, the TC certainly made some important contributions to the clarification and development of the law under the Rome Statute, out of which the expansion of the notion of 'active participation' may be the most significant one. The pronouncements on the characterization of armed conflicts show that this area will deserve sustained attention from the Court. The problems with constructing a convincing concept of co-perpetration and with making sense of Article 25(3), manifested in the disagreement between the majority and Judge Fulford as well as in the mens rea issue, will certainly resurface in the future practice of the Court and the last word has hardly been spoken. Finally, the TC's decisions on unreliable dual-status witnesses and Judge Fulford's approach to reviewing errors of law committed by the PTCs have highlighted problems, rather than presented solutions; both issues have the potential of impacting heavily on the way in which trials are run at the ICC-one by creating an incentive for victims not to testify in court, one by curtailing the TC's power to rule on questions of law.

All these contributions are important, but they are not revolutionary. Rather then propelling International Criminal Law or the ICC into a new era, the TC engaged in an incremental development of the law. We have to await the outcome of a possible appeal before drawing any final conclusions on the Lubanga case as a whole, but so far it seems safe to say that Lubanga is no Tadic, at least not as far as its impact on the law is concerned. But this should really have been clear from the start.

The second observation concerns how the Court perceives its own judicial function. The disagreements between the majority and Judge Odio Benito show that the TC was divided as to whether its function is limited to adjudicating upon the guilt vel non of the accused or whether it should seek to fulfill other functions as well. Should it cater to victims by pronouncing itself even on issues that are not directly relevant for the trial? Should the Chamber embark on stating the law even if such statements would be unnecessary obiter dicta? The Court is clearly still searching for a proper conception of the purpose of a trial judgment.

In many ways, Lubanga is only the beginning, the first step. No more and no less. 